\title{
Effects of $\boldsymbol{P}_{\mathbf{O}_{2}}$ at Flux State on the Fluorine Dissolution from Synthetic Steelmaking Slag in Aqueous Solution
}

\author{
Hoon-Ha LEE, ${ }^{1,2)}$ Soon-Ju KWON ${ }^{11}$ and Sung-Uk JANG ${ }^{11}$ \\ 1) Department of Materials Science and Engineering, POSTECH, Pohang, 790-784, Korea. E-mail: leehh@postech.ac.kr; \\ soonju@postech.ac.kr; sunguk79@postech.ac.kr $\quad$ 2) Resource Recycling Research Department, RIST, Pohang, 790-600, \\ Korea. E-mail: leehh@rist.re.kr
}

(Received on November 26, 2008; accepted on November 2, 2009)

\begin{abstract}
This paper studies effect of oxygen partial pressure at molten flux state on the fluorine dissolution from synthetic steelmaking slag solidified from the flux. The $P_{\mathrm{O}_{2}}$ 's were set as $6.6 \times 10^{-8}, 8.1 \times 10^{-5}, 2.9 \times 10^{-3}$, $1.5 \times 10^{-2}, 1.1 \times 10^{-1}$, or $6.6 \times 10^{3} \mathrm{~Pa}$, by changing the $\mathrm{CO} / \mathrm{CO}_{2}$ ratio of environmental flowing gas. The $\mathrm{Ca}: \mathrm{Al}$ : Fe atomic ratio of major cations of the slag (oxide) is $23: 9: 13$, and minor constituents are $\mathrm{Mg}(\sim 3$ at\%) and $\mathrm{F}(\sim 0.3 \mathrm{at} \%)$. The phases and their distribution is characterized using SEM, EDS (point and mapping), Rietveld refinement of XRD. Increase of $P_{\mathrm{O}_{2}}$ reduces fluorine dissolution, and the amounts of dissolution are higher than $1 \mathrm{mg} / \mathrm{L}$ when processed at $P_{\mathrm{O}_{2}}<10^{-2} \mathrm{~Pa}$, but are about or less than $0.5 \mathrm{mg} / \mathrm{L}$ when processed at $P_{\mathrm{O}_{2}}>10^{-2} \mathrm{~Pa}$. These results indicate that the low $P_{\mathrm{O}_{2}}$ processed slag has large fraction of low density Mayenite $\left(\mathrm{Ca}_{12} \mathrm{Al}_{14} \mathrm{O}_{33}\right)$ with most of fluorine in its sparse crystal structure, and liberates large amount of fluorine. On the contrary, the high $P_{\mathrm{O}_{2}}$ processed slag is mainly composed of high density Brownmillerite $\left(\mathrm{Ca}_{2} \mathrm{Al}_{x} \mathrm{Fe}_{2-x} \mathrm{O}_{5}\right)$, and the fluorine exists as $\mathrm{CaF}_{2}$ particles not to liberate fluorine easily. It is concluded that the fluorine dissolution is strongly governed by the amount of phases, the density and empty space of each crystal structure to accommodate fluorine, and their distribution.
\end{abstract}

KEY WORDS: steelmaking slag; fluorine dissolution; oxygen partial pressure; Brownmillerite; $\mathrm{CaO}_{-} \mathrm{Fe}_{t} \mathrm{O}-$ $\mathrm{Al}_{2} \mathrm{O}_{3}-\mathrm{CaF}_{2}$ system.

\section{Introduction}

Use of flux is inevitable in iron and steelmaking process. The appropriate amount of $\mathrm{CaF}_{2}$ is added to the flux in order to enhance the fluidity and reactivity for efficient process. Consequently the slag contains fluorine. The solidified slag becomes a by-product, not a waste, if it is utilized as a bed material for road construction or land reclaim. However, probability is that the fluorine dissolves from slag and pollutes soil and underground water. Therefore, the studies on the dissolution behavior of fluorine from slag and the fluorine immobilization are very important for environmental protection.

Several researches have been conducted in this respect, mainly for the slag from molten iron pre-treatment $(\mathrm{CaO}-$ $\mathrm{SiO}_{2}$ system) or secondary refining process $\left(\mathrm{CaO}-\mathrm{Al}_{2} \mathrm{O}_{3}\right.$ system). They have identified those influencing factors such as quenching rate of flux, chemical composition, mineral phases and crystallite size of slag, $\mathrm{pH}$ and temperature of aqueous solution on fluorine dissolution. ${ }^{1-3)}$ Also, various studies on the mechanism of fluorine dissolution and immobilization have been reported. ${ }^{4-8)}$

One has to remind, at the same time, that the oxygen blowing converter steelmaking process produces large amount of slag as well. Characteristics of the converter slags are; (1) incorporation of large amount of iron from the molten iron, (2) various oxidation state of iron due to the converter process, (3) high content of alumina due to reuse of secondary refining slag, and (4) incorporation of magnesia from the refractory, etc. Therefore, the converter slags are simply identified as a $\mathrm{CaO}-\mathrm{Al}_{2} \mathrm{O}_{3}-\mathrm{Fe}_{x} \mathrm{O}$ system in present study. Notwithstanding, it is hard to find researches focused on the converter slag.

This paper, thus, investigates details of synthetic converter slag solidified from flux at various oxygen partial pressures and the dissolution of fluorine from it into aqueous solution. Major constituents of the slag are oxides of $\mathrm{Ca}, \mathrm{Al}$ and $\mathrm{Fe}$, and minor ones are $2-3$ mass $\%$ of $\mathrm{Mg}$ and $3-5$ mass $\%$ of $F$. The result should deepen our understanding of the fluorine dissolution phenomena, which should help establishing the minimization of the fluorine dissolution.

\section{Experimental}

\subsection{Sample Preparation}

Samples were made with reagent grade chemicals; $\mathrm{CaCO}_{3}, \mathrm{Al}_{2} \mathrm{O}_{3}, \mathrm{Fe}_{2} \mathrm{O}_{3}, \mathrm{CaF}_{2}$. The $\mathrm{CaCO}_{3}$ was calcined for $24 \mathrm{~h}$ at $1273 \mathrm{~K}$ to remove $\mathrm{CO}_{2}$ and volatile contaminant, if any, and reduce to $\mathrm{CaO}$. Other chemicals were sufficiently dried before use. Powders of weight ratio of $\mathrm{CaO}: \mathrm{Al}_{2} \mathrm{O}_{3}$ : $\mathrm{Fe}_{2} \mathrm{O}_{3}: \mathrm{CaF}_{2}=45.3: 20.5: 32.2: 2.0$ were thoroughly mixed 
Table 1. Process parameters $\left(\mathrm{CO}_{2} / \mathrm{CO}\right.$ and $P_{\mathrm{O} 2}$ at $\left.1823 \mathrm{~K}\right)$, slag composition, and fluorine dissolution from slag.

\begin{tabular}{|c|c|c|c|c|c|c|c|c|c|}
\hline \multicolumn{2}{|c|}{ Sample no. } & 1 & 2 & 3 & 4 & 5 & 6 & average & st.dev \\
\hline \multirow{3}{*}{$\begin{array}{l}\text { Process } \\
\text { parameter }\end{array}$} & $\mathrm{CO}_{2} / \mathrm{CO}$ & $1 / 1000$ & $1 / 9$ & $4 / 6$ & $6 / 4$ & $8 / 2$ & $1000 / 1$ & & \\
\hline & $\mathrm{Po}_{2}(\mathrm{~Pa})^{(1)}$ & $6.6 \times 10^{-9}$ & $8.1 \times 10^{-5}$ & $2.9 \times 10^{-3}$ & $1.5 \times 10^{-2}$ & $1.1 \times 10^{-1}$ & $6.6 \times 10^{3}$ & & \\
\hline & $\log \mathrm{Po}_{2}$ & -8.18 & -4.09 & -2.53 & -1.83 & -0.98 & 3.82 & & \\
\hline \multirow{8}{*}{$\begin{array}{l}\text { Compositi } \\
\text { on, (at \%) }\end{array}$} & $\mathrm{Ca}$ & 23.2 & 23.3 & 23.1 & 22.8 & 23.7 & 22.6 & 23.0 & 0.37 \\
\hline & $\mathrm{Al}$ & 9.2 & 9.0 & 9.1 & 8.2 & 8.0 & 9.2 & 8.7 & 0.53 \\
\hline & $\mathrm{Fe}$ & 12.7 & 12.9 & 12.7 & 13.3 & 12.8 & 12.2 & 12.7 & 0.35 \\
\hline & $\mathrm{Mg}$ & 2.6 & 2.7 & 2.9 & 3.7 & 3.5 & 3.6 & 3.16 & 0.50 \\
\hline & $\mathrm{F}$ & 0.38 & 0.34 & 0.35 & 0.35 & 0.31 & 0.32 & 0.34 & 0.02 \\
\hline & Metallic $\mathrm{Fe}$ & 1.67 & 1.61 & 1.38 & 1.16 & 0.91 & 0.12 & & \\
\hline & $\mathrm{Fe}^{2+}$ & 3.81 & 3.20 & 2.14 & 1.95 & 1.18 & 0.34 & & \\
\hline & $\mathrm{Fe}^{3+}$ & 7.22 & 8.09 & 9.18 & 10.19 & 10.72 & 11.74 & & \\
\hline \multicolumn{2}{|c|}{ Dissolved fluorine $(\mathrm{mg} / \mathrm{l})$} & 1.84 & 1.40 & 1.19 & 0.50 & 0.59 & 0.45 & & \\
\hline
\end{tabular}

(1) Calculation of $\mathrm{Po}_{2}$ at $1823 \mathrm{~K}$ is based on: $\mathrm{CO}(\mathrm{g})+\frac{1}{2} \mathrm{O}_{2}=\mathrm{CO}_{2}(\mathrm{~g}) ; \Delta \mathrm{G}^{\circ}=-281,000+85.23 \mathrm{~T}(\mathrm{~J} / \mathrm{mol})$

using a pestle-and-mortar. This is equivalent to the cationic molar ratio of $\mathrm{Ca}: \mathrm{Fe}: \mathrm{Al}=2: 1: 1$, which is typical Brownmillerite composition $\left(\mathrm{Ca}_{2}(\mathrm{Al}, \mathrm{Fe})_{2} \mathrm{O}_{5}\right)$. The mixture of $30 \mathrm{~g}$ was placed in a $\mathrm{MgO}$ crucible $(99 \% \mathrm{MgO})$, and was melted for $1 \mathrm{~h}$ at $1823 \mathrm{~K}$ and at various $P_{\mathrm{O}_{2}}$. Solidification was followed between a pair of copper plates to make a synthetic converter slag.

The $P_{\mathrm{O}_{2}}$ during flux melting was controlled by continuous flowing $\left(270 \mathrm{~cm}^{3} / \mathrm{min}\right)$ of a mixture gas of appropriate $\mathrm{CO}_{2} / \mathrm{CO}$ ratio. There may be contaminant like oxygen and moisture in $\mathrm{CO}_{2}$ and $\mathrm{CO}$ gas used in this experiment, therefore prior to the gas mixing, the oxygen in each gas was removed to be less than $1 \mathrm{ppb}$ by passing through a commercial oxygen moisture trap. Table 1 shows the mixing ratio of $\mathrm{CO}_{2} / \mathrm{CO}$ and the calculated $P_{\mathrm{O}_{2}}$. The calculation of $P_{\mathrm{O}_{2}}$ is based on the free energy of the reaction of $\mathrm{CO}(\mathrm{g})+1 / 2 \mathrm{O}_{2}=$ $\left.\mathrm{CO}_{2}(\mathrm{~g}): \Delta G^{\circ}=-281000+85.23 T(\mathrm{~J} / \mathrm{mol}){ }^{9}{ }^{9}\right)$ Referring to the Richardson diagram at $1823 \mathrm{~K}$, metallic $\mathrm{Fe}$ is stable in the $P_{\mathrm{O}}$ of lower than $10^{-3} \mathrm{~Pa}$, and $\mathrm{Fe}^{2+}$ is stable at higher. ${ }^{10,11)} \mathrm{Ca}, \mathrm{Al}$, and $\mathrm{Mg}$ are stable in their oxidized state with the valence $2+, 3+$, and $2+$, respectively, in general.

\subsection{Slag Characterization}

Total Fe (T-Fe) content in the slag was measured using an inductively coupled plasma atomic emission spectroscopy (ICP-AES). Contents of metallic $\mathrm{Fe}(\mathrm{M}-\mathrm{Fe})$, and $\mathrm{Fe}^{2+}$ were characterized using a titration method ${ }^{12,13)}$ according to the Korean Standards, KS E 30162003 and KS E ISO 5416 2003 , respectively. Content of $\mathrm{Fe}^{3+}$ was determined by subtracting $\mathrm{M}-\mathrm{Fe}$ and $\mathrm{Fe}^{2+}$ from T-Fe.

Total fluorine (T-F) content in the slag was determined according to the Korean Soil Contamination Test Standards. The procedure of this is as follows:

(1) The slag sample was pulverized to powder of smaller than $75 \mu \mathrm{m}$.

(2) The mixture of $1 \mathrm{~g}$ of the slag powder and $5 \mathrm{~g}$ of $\mathrm{CaO}$
(99.9\%) was calcined for $5 \mathrm{~h}$ at $773 \mathrm{~K}$, followed by $2 \mathrm{~h}$ at $1073 \mathrm{~K}$ and air cooling.

(3) The sample was charged in a mixed solution of distilled water $(25 \mathrm{~mL})$ and $70 \%$ perchloric acid $(50 \mathrm{~mL})$, and was heated in Kjeldahl system.

(4) Distilled solution was collected into a flask, which contained $50 \% \mathrm{NaOH}$ and nitrophenol indicator.

(5) The fluorine content in the distilled solution was analyzed using ion-chromatography.

Microstructure of the synthetic slag was characterized using a secondary electron microscopy equipped with energy dispersive spectroscopy (EDS). Point and area composition analysis and mapping with EDS provide rough figures on the overall composition, the phase composition, and the elemental distribution, respectively.

Mineral phases in the synthetic slag were characterized using an X-ray diffractometer. The radiation was $\operatorname{CuK} \alpha_{1}$ from a rotating anode $(50 \mathrm{kV}, 180 \mathrm{~mA})$. After performing instrumental zero point adjustment for each measurement, a $\theta-2 \theta$ diffractogram was obtained by step scan (step size $\Delta 2 \theta=0.01^{\circ}$, and count $2 \mathrm{~s}$ at each step).

\subsection{Fluorine Dissolution Test}

According to the Japan Industrial Standards (JIS-K0102; Test procedure of fluorine dissolution from slag), $5 \mathrm{~g}$ of slag powder smaller than $75 \mu \mathrm{m}$ was put in $50 \mathrm{~g}$ of distilled water and stirred with $200 \mathrm{rpm}$ for $6 \mathrm{~h}$ at $298 \mathrm{~K}$. Content of fluorine in the solution was analyzed using ion-chromatography as in the above-mentioned fluorine analysis in the slag.

\section{Results}

\subsection{Slag Composition}

Slag compositions are listed in Table 1. Average atomic ratio is $\mathrm{Ca}: \mathrm{Al}: \mathrm{Fe}: \mathrm{Mg}: \mathrm{O}: \mathrm{F}=23: 8.7: 12.7: 3.16: 52.0$ : 


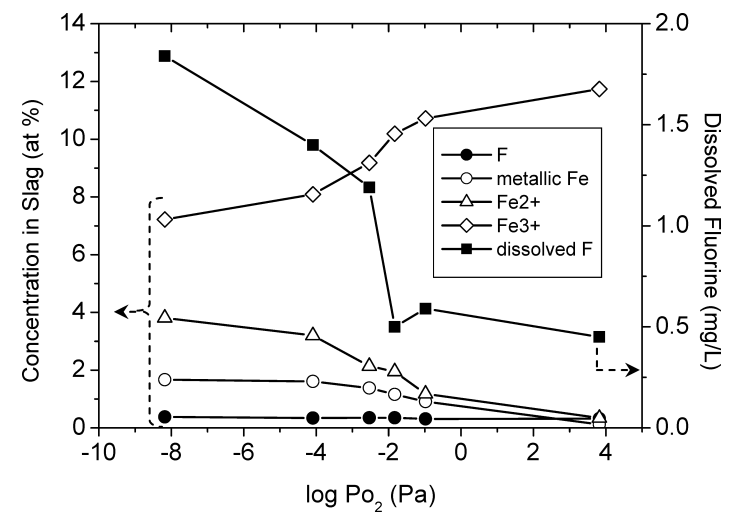

Fig. 1. Variations of composition of slag and fluorine dissolution from slag with oxygen potential during melting.

0.34. Variation of the content of each element, especially the total fluorine content, among the samples is insignificant with standard deviation of less than 0.5 at $\%$. It is noted that there are appreciable gain of $\mathrm{Mg}$ and loss of $\mathrm{Al}$ from initial mixing composition, presumably due to dissolution from $\mathrm{MgO}$ crucible and $\mathrm{Al}$ evaporation from melt during the flux process, respectively. However, the trend is uniform among the samples and should have little consequence in present investigation.

The compositions of fluorine, metallic $\mathrm{Fe}, \mathrm{Fe}^{2+}$, and $\mathrm{Fe}^{3+}$ in the slag are plotted against oxygen potential in Fig. 1. Significance is that the amount of $\mathrm{Fe}^{3+}$ indeed increases with the increase of $P_{\mathrm{O}_{2}}$. Contrary, the flux processes at $P_{\mathrm{O}_{2}}<10^{-2} \mathrm{~Pa}$ produce appreciable amount of metallic $\mathrm{Fe}$. Another point to be noted is that $3+$ is the major valency of Fe in the rapidly solidified slag, though the equilibrium thermodynamics and Richardson diagram predicts $2+$ should be the major state at the flux state. This implies that the oxidation kinetics during the solidification in atmospheric environment $\left(P_{\mathrm{O}_{2}}\right.$ of about $\left.20 \mathrm{kPa}\right)$ is very rapid. However, variation of the total fluorine content is not significant.

\subsection{SEM-EDS Analysis}

SEM images and EDS fluorine mapping at $\times 1000$ magnification shown in Fig. 2 indicate very complex microstructures. The phases can be roughly categorized by 5 scale of brightness (brightest, bright, medium, dark, and darkest). Figure 3 shows typical EDS spectra at the points relevant to those phases. The brightest region (a) produces predominant $\mathrm{Fe}$ peaks without oxygen, whereas the dark phases (d1) consists of oxides (or fluorides) of $\mathrm{Ca}, \mathrm{Al}$, and $\mathrm{Mg}$. The brightest phase (a) seems to be metallic Fe, referring to the image contrast theory of SEM (a phase having more loosely bound electrons releases more secondary electrons making a bright SEM image). The dark phases (d1) and (d2) are mostly ionic compounds, where most of the outer electrons are working for the ionic bond. However, the spatial resolution of EDS limits a precise composition analysis of each phase. Rather, careful inspection with composition map from EDS (not shown) and XRD Rietveld analysis (see below) informed that phases can be roughly classified as: (a) brightest metallic $\mathrm{Fe}$, (b) brighter $\mathrm{Fe}-$ $(\mathrm{Ca}, \mathrm{Mg})-\mathrm{O}$, (c) grey $\mathrm{Ca}-(\mathrm{Fe}, \mathrm{Al})-\mathrm{O}$ (mainly Brownmillerite), (d) darker ( $\mathrm{Ca}, \mathrm{Al}, \mathrm{Mg})-(\mathrm{O}, \mathrm{F})$ (mainly Mayenite),
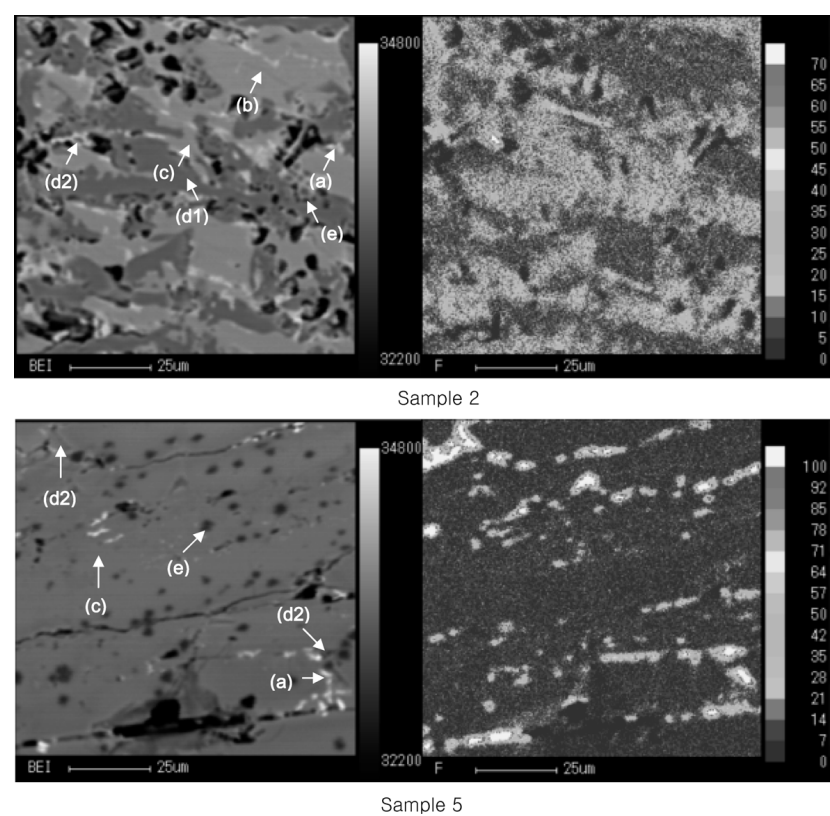

Fig. 2. SEM images and fluorine mapping of the slag (sample 2 and sample 5). (a) brightest metallic Fe, (b) brighter $\mathrm{Fe}-\mathrm{Ca}(\mathrm{Mg})-\mathrm{O}$, (c) grey $\mathrm{Ca}-(\mathrm{Fe}, \mathrm{Al})-\mathrm{O}$ (mainly Brownmillerite), (d1) darker $\mathrm{Ca}-\mathrm{Al}-\mathrm{O}$, (d2) darker $\mathrm{Ca}-\mathrm{F}$, and (e) darkest $\mathrm{Mg}-\mathrm{O}$.

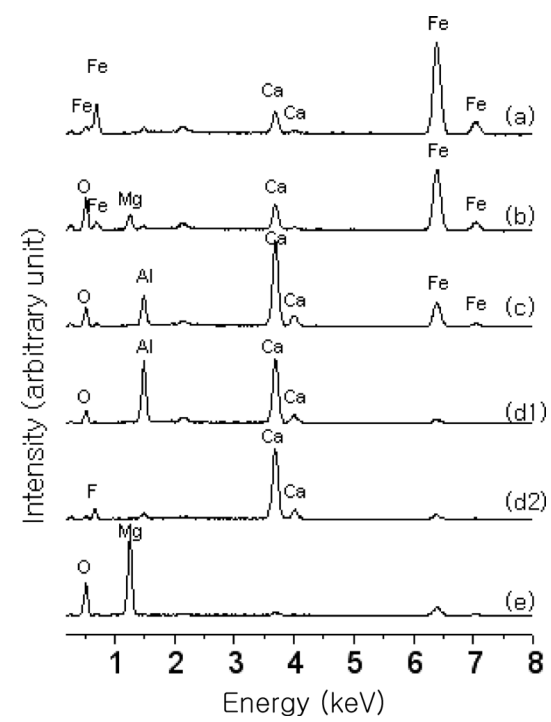

Fig. 3. Typical EDS Spectra from roughly classified 5 phase regions. (a) Brightest metallic $\mathrm{Fe}$, (b) brighter $\mathrm{Fe}-$ $\mathrm{Ca}(\mathrm{Mg})-\mathrm{O}$, (c) grey $\mathrm{Ca}-(\mathrm{Fe}, \mathrm{Al})-\mathrm{O}$ (mainly Brownmillerite), (d1) darker $\mathrm{Ca}-\mathrm{Al}-\mathrm{O}$, (d2) darker $\mathrm{Ca}-\mathrm{F}$, and (e) darkest $\mathrm{Mg}-\mathrm{O}, \mathrm{Ca}-\mathrm{O}$ (not shown).

and (e) darkest ( $\mathrm{Ca}, \mathrm{Mg})-\mathrm{O}$ (Calcia and Magnesia). A feature worth to note is that fluorine forms isolated particles of compound with $\mathrm{Ca}$ in samples 3 to $6\left(P_{\mathrm{O}_{2}}>10^{-2} \mathrm{~Pa}\right)$, where as solutionizes rather uniformly in the samples 1 and 2 $\left(P_{\mathrm{O}_{2}}<10^{-2} \mathrm{~Pa}\right)$.

It is found in Fig. 4 that X-ray diffraction patterns of samples 1 to 6 are apparently different each other. But they are very complex and require a computer assisted analysis. Figure 5 shows a typical result of Rietveld refinement. Table 2 summarizes the volume percentages of mineral phases determined by this method (with accuracy of about $10 \%$ in relative). It is obvious that the fraction of 
$\mathrm{Ca}_{2}(\mathrm{Fe}, \mathrm{Al})_{2} \mathrm{O}_{5}$ and $\mathrm{CaF}_{2}$ increase at higher $P_{\mathrm{O}_{2}}$, but those of other phases decrease. The result coincides with the above EDS mapping, where fluorine disperses in samples 1, 2, but forms phase of $\mathrm{Ca}-\mathrm{F}$ with dark contrast.
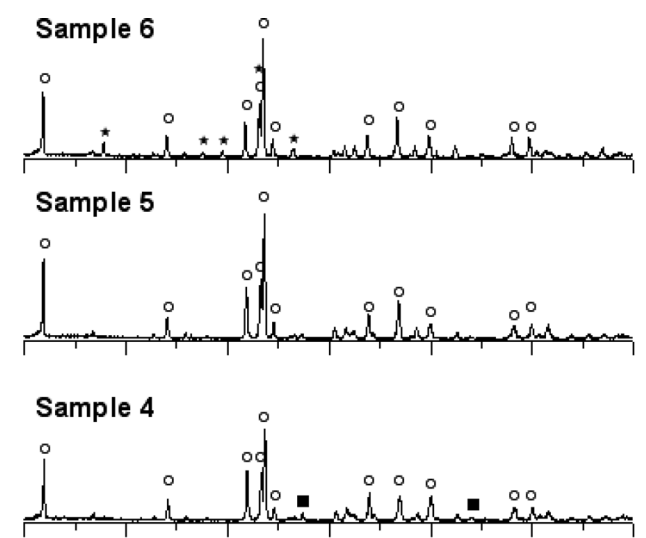

Sample 3

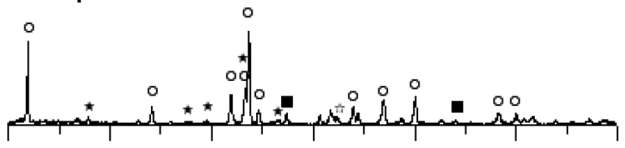

Sample 2

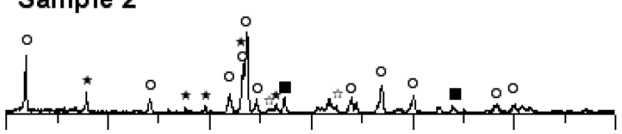

Sample 1

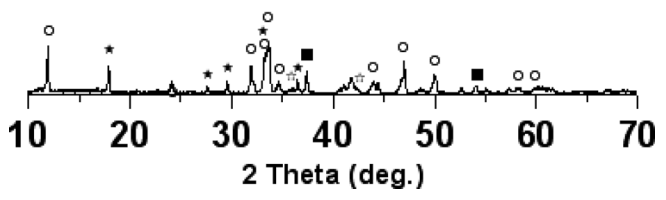

Fig. 4. XRD patterns of samples 1 to 6 listed in Table 1. $\mathbf{a}: \mathrm{CaO}$, $\mathrm{O}: \mathrm{Ca}_{2}(\mathrm{Fe}, \mathrm{Al})_{2} \mathrm{O}_{5}$ (mainly Brownmillerite), $\star \mathrm{Ca}_{12} \mathrm{Al}_{14}$ $\mathrm{O}_{33}$, and is: $\mathrm{Mg}_{1-x} \mathrm{Fe}_{x} \mathrm{O}$.

\subsection{Fluorine Dissolution}

Table 1 also includes the results of fluorine dissolution test. An important trend is that the amount of fluorine dissolution is apparent from the slag solidified from the molten flux at $P_{\mathrm{O}_{2}}<10^{-2} \mathrm{~Pa}$ (samples 1-3), but it reduces to insignificant level at $P_{\mathrm{O}_{2}}>10^{-2} \mathrm{~Pa}$ (samples 4-6). It behaves roughly exponential decrease to approach about $0.5 \mathrm{mg} / \mathrm{L}$ fluorine in this specific test. However, an exact correlation is hard to be found.

\section{Discussion}

\subsection{Phases and Fluorine Distribution in the Slag}

The result of the Rietveld refinement (Table 2) tells that

Table 2. Volume percent of mineral phases determined by Rietveld analysis in slags (accuracy of about $10 \%$ in relative).

\begin{tabular}{|c|c|c|c|c|c|c|}
\hline Sample no. & 1 & 2 & 3 & 4 & 5 & 6 \\
\hline $\begin{array}{c}\text { Browmillerite } \\
\mathrm{Ca}_{2}(\mathrm{Fe}, \mathrm{Al})_{2} \mathrm{O}_{5}\end{array}$ & 56 & 70 & 72 & 85 & 95 & 83 \\
\hline $\begin{array}{c}\text { Brownmillerite } \\
\mathrm{Ca}_{2} \mathrm{Fe}_{2} \mathrm{O}_{5}\end{array}$ & - & 4 & 8 & 6 & 2 & 3 \\
\hline $\begin{array}{c}\text { Mayenite } \\
\mathrm{Ca}_{12} \mathrm{Al}_{14} \mathrm{O}_{33}\end{array}$ & 18 & 11 & 4 & - & - & 11 \\
\hline $\begin{array}{c}\text { Periclase } \\
\mathrm{Mg}_{1-\mathrm{x}} \mathrm{Fe} \mathrm{x}_{\mathrm{O}}\end{array}$ & 11 & 6 & 7 & 5 & 3 & 3 \\
\hline $\begin{array}{c}\mathrm{Calcia} \\
\mathrm{CaO}\end{array}$ & 15 & 9 & 8 & 3 & $<1$ & - \\
\hline Iron & 0.8 & 0.5 & $<0.5$ & $<0.5$ & $<0.5$ & - \\
\hline a-Fe & - & - & 1 & 1 & 1 & $<1$ \\
\hline $\begin{array}{c}\text { Fluorite } \\
\text { CaF }\end{array}$ & & & & & & \\
\hline
\end{tabular}

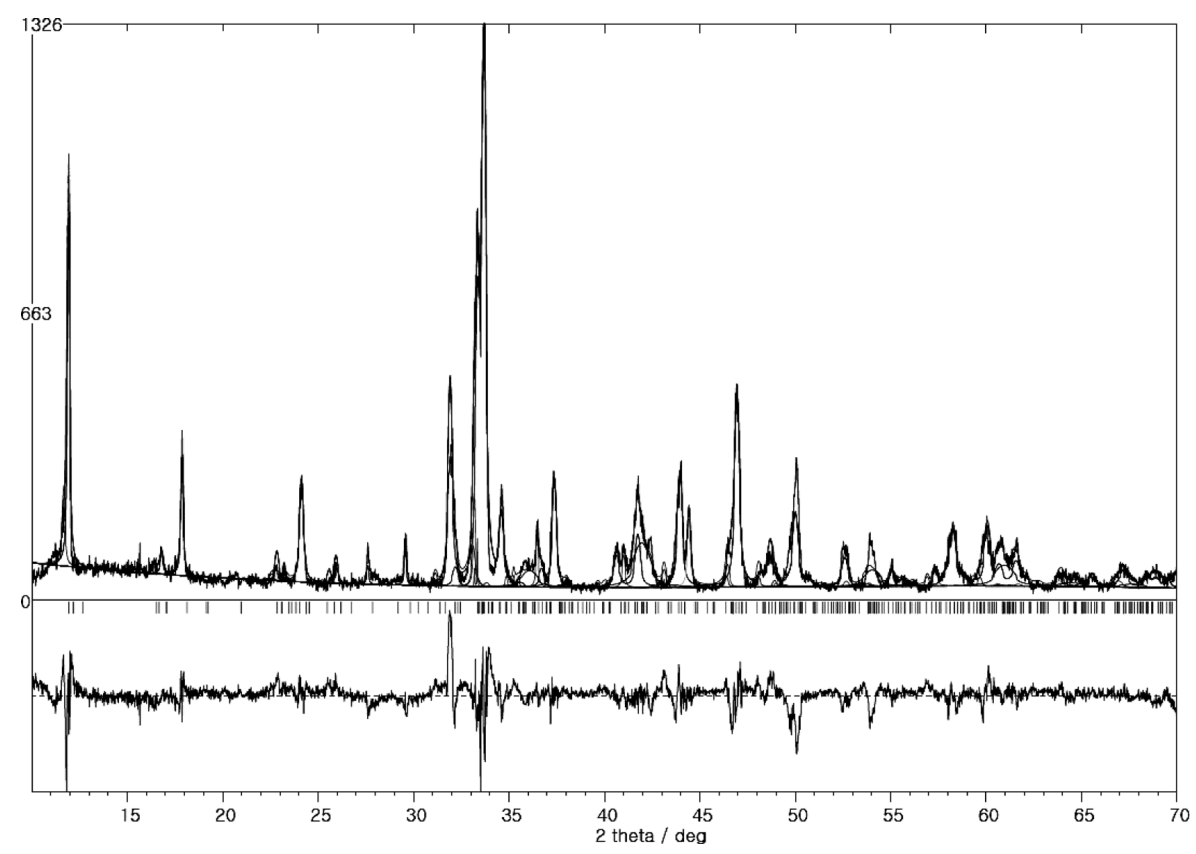

Fig. 5. An example of Rietveld analysis for sample 2. 
Table 3. The space groups and densities of $\mathrm{Ca}_{2} \mathrm{Fe}_{2} \mathrm{O}_{5}$, $\mathrm{Ca}_{2} \mathrm{Fe}_{1.1} \mathrm{Al}_{0.9} \mathrm{O}_{5}, \mathrm{Ca}_{2} \mathrm{Al}_{2} \mathrm{O}_{5}$, and $\mathrm{Ca}_{12} \mathrm{Al}_{14} \mathrm{O}_{33}$.

\begin{tabular}{|c|c|c|c|c|}
\hline Composition & $\mathrm{Ca}_{2} \mathrm{Fe}_{2} \mathrm{O}_{5}$ & $\mathrm{Ca}_{2} \mathrm{Fe}_{1.1} \mathrm{Al}_{0.9} \mathrm{O}_{5}$ & $\mathrm{Ca}_{2} \mathrm{Al}_{2} \mathrm{O}_{5}$ & $\mathrm{Ca}_{12} \mathrm{~A}_{14} \mathrm{O}_{33}$ \\
\hline $\begin{array}{c}\text { Name or } \\
\text { structure }\end{array}$ & Brownmillerite & $\begin{array}{c}\text { Brownmillerite } \\
\text { structure }\end{array}$ & Mayenite \\
\hline Space Group & $P c m n$ & $12 m b$ & $12 m b$ & $1-43 d$ \\
\hline $\begin{array}{c}\text { Density } \\
\left(\mathrm{g} / \mathrm{cm}^{3}\right)\end{array}$ & 3.185 & 3.778 & 3.482 & 2.602 \\
\hline
\end{tabular}

low $P_{\mathrm{O}_{2}}$ processes produces appreciable amount of Mayenite, Periclase $\left(\mathrm{Mg}_{1-x} \mathrm{Fe}_{x} \mathrm{O}\right)$, Calcia $(\mathrm{CaO})$, and $\alpha$-Fe. The volume fraction of Brownmillerite increases with increasing $P_{\mathrm{O}_{2}}$, at the expense of those phases. The trend is quite reasonable because the $\mathrm{Fe}$ should oxidize toward higher valency, i.e. $3+$, with the increase of $P_{\mathrm{O}_{2}}$, and forms more oxides with $\mathrm{Fe}^{3+}$ valency, i.e. Brownmillerite. However, forming the terminal phase of $\mathrm{Ca}_{2} \mathrm{Fe}_{2} \mathrm{O}_{5}$ is not preferable in the existence of Al. Peculiar but hard to understand is the increase of Mayenite volume fraction to above $10 \%$ in the sample 6. This is not possible, unless there exist a pseudoeutectoid transition pressure between $P_{\mathrm{O}_{2}}=10^{-1}$ and $10^{3} \mathrm{~Pa}$. However, any relevant thermodynamic report could not be found.

The Brownmillerite, represented by $\mathrm{Ca}_{2} \mathrm{Fe}_{2-x} \mathrm{Al}_{x} \mathrm{O}_{5}$, has a very wide range of $x=0.3-1$. Fe rich terminal composition is $\mathrm{Ca}_{2} \mathrm{Fe}_{2} \mathrm{O}_{5}$ (in reality there should be some solubility of $\mathrm{Al}$ in it). However, the other end member, $\mathrm{Ca}_{2} \mathrm{Al}_{2} \mathrm{O}_{5}$, exists only at high pressure and temperature. Rather, Mayenite, represented by $\mathrm{Ca}_{12} \mathrm{Al}_{14} \mathrm{O}_{33}$, is the stable phase. Consequently, the computer assisted Rietveld analysis could not detect the phase. The space groups and densities are as follow (Table 3).

Like most of complex oxide materials, the crystal structures of above phases consist of layers of oxygen octahedron, in which oxygen tetrahedrons are intercalated with different occupancy and handedness. The Brownmillerite (space group; $I_{2 m b}$ ) has the highest density, and the Fe-rich terminal phase $\left(\mathrm{Ca}_{2} \mathrm{Fe}_{2} \mathrm{O}_{5} ; P_{c m n}\right)$ has lower density (even though the molecular weight is higher). This implies that $\mathrm{Ca}_{2} \mathrm{Fe}_{2} \mathrm{O}_{5}$ has more empty space (i.e. less degree of tetrahedron intercalation) than Brownmillerite. The other end members show similar behavior, i.e. density of Mayenite is about $25 \%$ lower than $\mathrm{Ca}_{2} \mathrm{Al}_{2} \mathrm{O}_{5}$ (Brownmillerite structure). In other word, the Mayenite structure has approximately $33 \%$ more empty space than the Brownmillerite structure. ${ }^{14)}$ This empty space should be an appropriate site to incorporate foreign atoms, such as fluorine.

This structural understanding coincides with the results of fluorine mapping by EDS. In samples 1 and 2, fluorine disperses predominantly in the low density Mayenite, which exists over entire area of the sample. Contrary, in samples 3 , 4, and 5, fluorine forms $\mathrm{CaF}_{2}$ particle, because Brownmillerite does not have sufficient space to accommodate the element. In sample 6 , which has $11 \mathrm{vol} \%$ of Mayenite, and fluorine incorporates in the phase.

\subsection{Oxygen Partial Pressure and Fluorine Dissolution}

Much fluorine dissolves out from samples 1, 2, and 3, which solidified from flux at low $P_{\mathrm{O}_{2}}$. Those samples have large volume fraction of Mayenite (see Table 2, the Rietveld refinement result), which mainly contains fluorine (see the fluorine mapping by EDS). As discussed in above, this seems quite natural, because Mayenite has low density and much empty space in its intercalated layer of tetrahedrons, which should be a highly probable site to incorporate fluorine. However, note that local charge balance should be satisfied in the oxide phase of ionic bonding. Thus, the singly charged fluorine anion should hardly make stable polyhedron with doubly charged oxygen anion. This tempts to say that the fluorine ion has unstable bonding in the structure, or exists as a neutral atom. Naturally, the fluorine ion (or atom) is vulnerable to dissolution. The amount of fluorine dissolution, thus, has a strong correlation with the volume fraction of Mayenite.

In the samples 4 and 5, volume fractions of Mayenite are negligible, and fluorine exists as fluorite, which is confirmed by both the results of fluorine mapping and Rietveld refinement. This state of fluorine is much less vulnerable to dissolution, and the amount of fluorine dissolution is insignificant.

Another point is the effect of morphology. In the samples 1 and 2, Mayenite distribution is homogeneous, and the fluorine distribution as well. Making the dissolution test using pulverized $75 \mu \mathrm{m}$ size powder, the Mayenite (in the samples 1 and 2) shares large area of interface with water at the powder surface, since the phase has large volume fraction and evenly distributed over the sample (see SEM image and EDS mapping in Fig. 2). Contrary in the samples 4 and 5, fluorine forms small volume fraction of $\mathrm{CaF}_{2}$ particle of small volume fraction (also see the above results). The particles have low chance to be exposed at the surface of pulverized powder. Thus the interfacial area between $\mathrm{CaF}_{2}-$ water should be small, and explains the insignificant dissolution of fluorine.

There is a hypothesis that dissolved fluorine re-fixes itself at the hydrated surface of low density, especially at the hydrated Brownmillerite., ${ }^{45}$

\subsection{Hydrated Mineral Phases and Fluorine Dissolu- tion}

Figure 6 shows the XRD results of slag powder hydrated during shaking with water for $6 \mathrm{~h}$. For low $P_{\mathrm{O}_{2}}$ (samples 1 to 3 ), the formation of $\mathrm{Ca}_{2}(\mathrm{Al}, \mathrm{Fe})_{2} \mathrm{O}_{5}$ is minute and coexists with Mayenite $\left(\mathrm{C}_{12} \mathrm{~A}_{7}\right)$ as the mineral phases of slag. The hydrates of these slags mainly consist of $\mathrm{Ca}_{3}(\mathrm{Al}, \mathrm{Fe})_{2}(\mathrm{OH})_{12}$, which is the main hydrated mineral phase of $\mathrm{Ca}_{2}(\mathrm{Al}, \mathrm{Fe})_{2} \mathrm{O}_{5}$, and $\mathrm{C}_{3} \mathrm{~A} \cdot \mathrm{Ca}(\mathrm{OH})_{2} \cdot 18 \mathrm{H}_{2} \mathrm{O}$ of $\mathrm{C}_{12} \mathrm{~A}_{7}$. According to the report given by $\mathrm{He}$ and Suito, ${ }^{7)}$ fluorine dissolved from the slag is substituted and fixed to the $\mathrm{OH}^{-}$of these hydrates and hence the decrease in the amount of fluorine dissolution. The fluorine immobilizing ability of these hydrates for the above case is known to be $\mathrm{Ca}_{3}(\mathrm{Al}, \mathrm{Fe})_{2}(\mathrm{OH})_{12-x} \mathrm{~F}_{x} \gg$ $\mathrm{C}_{3} \mathrm{~A} \cdot \mathrm{Ca}(\mathrm{OH})_{2-x} \mathrm{~F}_{x} \cdot 18 \mathrm{H}_{2} \mathrm{O}$.

Therefore, for low $P_{\mathrm{O}_{2}}$, the rate of hydration reaction of $\mathrm{C}_{12} \mathrm{~A}_{7}$, one of the mineral phases of slag, is fast increasing the amount of fluorine dissolution as stated before. However, formation of the hexagonal phase $\mathrm{C}_{3} \mathrm{~A} \cdot \mathrm{Ca}(\mathrm{OH})_{2}$. $18 \mathrm{H}_{2} \mathrm{O}$ is rich as shown in Fig. 7 for sample 2. The fluorine immobilizing ability of this mineral phase is low and thus the amount of fluorine dissolution is significant. 

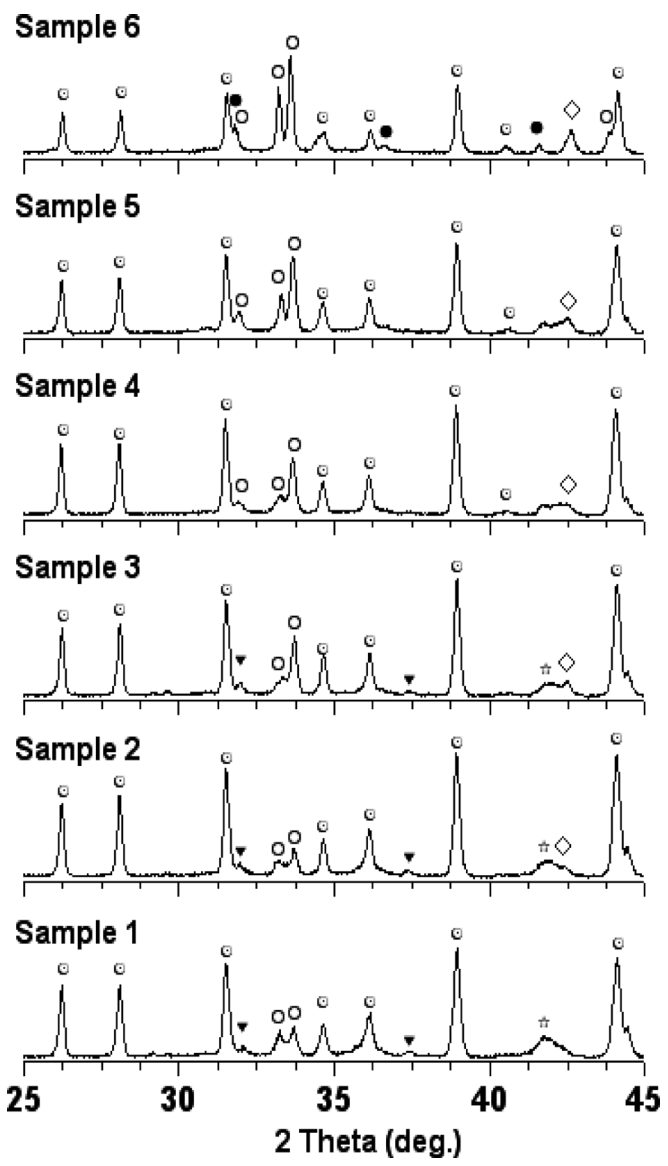

Fig. 6. Results of XRD analysis for the hydrated slags of samples 1 to 6: solid/liquid mass ratio $=1 / 10$, shaking time $=$ 6h. $\bigcirc: \mathrm{Ca}_{2}(\mathrm{Fe}, \mathrm{Al})_{2} \mathrm{O}_{5}, \odot: \mathrm{Ca}_{3}(\mathrm{Al}, \mathrm{Fe})_{2}(\mathrm{OH})_{12-x} \mathrm{~F}_{x}$, $\mathrm{Ca}_{3} \mathrm{Al}_{2}(\mathrm{OH})_{12-x} \mathrm{~F}_{x}, \mathbf{\nabla}: \mathrm{C}_{3} \mathrm{~A} \cdot \mathrm{Ca}(\mathrm{OH})_{2-x} \mathrm{~F}_{x} \cdot 18 \mathrm{H}_{2} \mathrm{O}$, 攻: $\mathrm{FeO}$, and $\diamond: \mathrm{MgO}$.
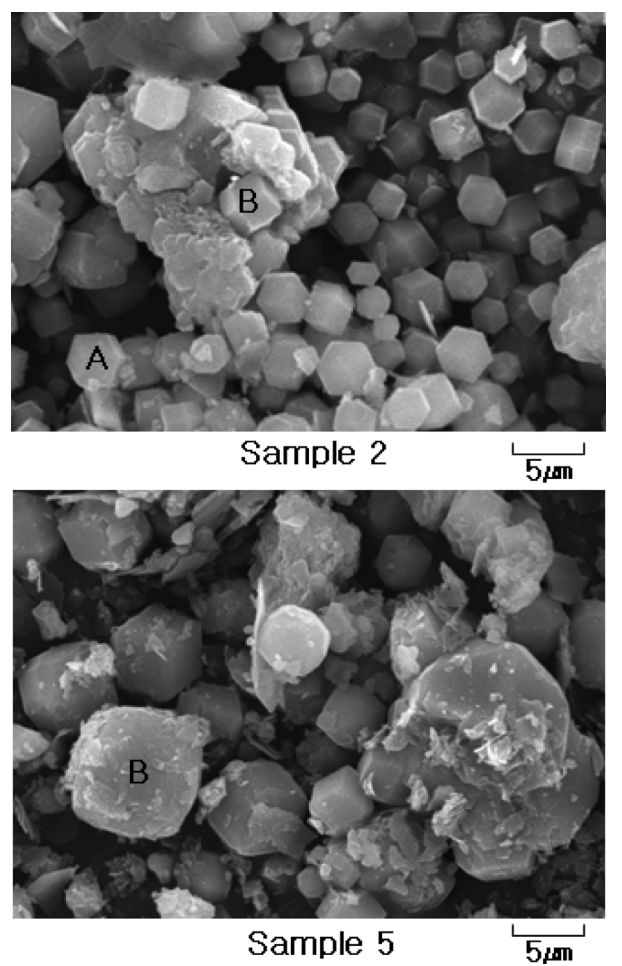

Fig. 7. Morphologies of hydrated slags under shaking condition with samples 2 and 5 . (A) $3 \mathrm{CaO} \cdot \mathrm{Al}_{2} \mathrm{O}_{3} \cdot \mathrm{Ca}(\mathrm{OH})_{2-x} \mathrm{~F}_{x}$. $18 \mathrm{H}_{2} \mathrm{O}$ (hexagonal phase) and (B) $\mathrm{Ca}_{3}(\mathrm{Al}, \mathrm{Fe})_{2}(\mathrm{OH})_{12-x} \mathrm{~F}_{x}$ (cubic phase)
For high $P_{\mathrm{O}_{2}}$ (samples 4 to 6), the formation of $\mathrm{Ca}_{2}(\mathrm{Al}, \mathrm{Fe})_{2} \mathrm{O}_{5}$ mineral phase in slag is obvious. The rate of hydration reaction of the $\mathrm{Ca}_{2}(\mathrm{Al}, \mathrm{Fe})_{2} \mathrm{O}_{5}$ mineral phase is slow. However, the formation of cubic $\mathrm{Ca}_{3}(\mathrm{Al}, \mathrm{Fe})_{2}$ $(\mathrm{OH})_{12-x} \mathrm{~F}_{x}$ is rich as shown in Fig. 7 for sample 5. The fluorine immobilizing ability of this mineral phase is high and thus the amount fluorine dissolution is insignificant.

On the other hand, according to Suito et al., small amount of $\mathrm{Ca}_{3}(\mathrm{Al}, \mathrm{Fe})_{2}(\mathrm{OH}, \mathrm{F})_{12}$ is formed when $\mathrm{C}_{12} \mathrm{~A}_{7}$ contained $\mathrm{F}$, as well as $\mathrm{Fe}$ coexists with $\mathrm{Ca}_{2} \mathrm{Fe}_{2} \mathrm{O}_{5}$ and this phase accelerates the immobilization of fluorine dissolve from the slag as shown in the reactions below. ${ }^{4}$

$$
\begin{aligned}
\mathrm{C}_{12} \mathrm{~A}_{7}+ & 12 \mathrm{CaO}+n \mathrm{H}_{2} \mathrm{O}+\mathrm{F}^{-} \\
\rightarrow & \left\{\begin{array}{l}
\mathrm{C}_{3} \mathrm{~A} \cdot \mathrm{Ca}(\mathrm{OH})_{2-x} \mathrm{~F}_{x} \cdot 18 \mathrm{H}_{2} \mathrm{O}^{*} \\
\mathrm{C}_{3} \mathrm{~A} \cdot x \mathrm{H}_{2} \mathrm{O}^{* *}(x=8-10) \\
\mathrm{C}_{2} \mathrm{~A} \cdot 8 \mathrm{H}_{2} \mathrm{O}^{* *}
\end{array}\right\} \text { hexagonal hydraes } \\
& * \text { : major phase, **: minor phase }
\end{aligned}
$$

$$
\begin{aligned}
& \mathrm{C}_{3} \mathrm{~A} \cdot \mathrm{Ca}(\mathrm{OH})_{2-x} \mathrm{~F}_{x} \cdot 18 \mathrm{H}_{2} \mathrm{O} \\
& \rightarrow \mathrm{C}_{2} \mathrm{~A} \cdot 6 \mathrm{H}_{2} \mathrm{O}+2 \mathrm{Ca}(\mathrm{OH})_{2}+\mathrm{F}^{-}+n \mathrm{H}_{2} \mathrm{O} \\
& \left.\begin{array}{l}
\mathrm{C}_{2} \mathrm{~A} \cdot 8 \mathrm{H}_{2} \mathrm{O} \\
\mathrm{C}_{2} \mathrm{~A} \cdot 6 \mathrm{H}_{2} \mathrm{O}
\end{array}\right\}+1 / 3 \mathrm{Al}(\mathrm{OH})_{3}+\mathrm{F}^{-} \\
& \rightarrow \mathrm{Ca}_{3} \mathrm{Al}_{2}(\mathrm{OH})_{12-x} \mathrm{~F}_{x}(\text { cubic })+n \mathrm{H}_{2} \mathrm{O}
\end{aligned}
$$

In sample 6 , the $\mathrm{Ca}_{2}(\mathrm{Al}, \mathrm{Fe})_{2} \mathrm{O}_{5}$ mineral phase is richly formed and coexists with small amount of $\mathrm{C}_{12} \mathrm{~A}_{7}$. The hydrates of these mineral phases take part in the formation of $\mathrm{Ca}_{3}(\mathrm{Al}, \mathrm{Fe})_{2}(\mathrm{OH})_{12-x} \mathrm{~F}_{x}$, a hydrate of $\mathrm{Ca}_{2}(\mathrm{Al}, \mathrm{Fe})_{2} \mathrm{O}_{5}$, and $\mathrm{Ca}_{3} \mathrm{Al}_{2}(\mathrm{OH})_{12-x} \mathrm{~F}_{x}$, by the acceleration of the hydration reaction of $\mathrm{C}_{12} \mathrm{~A}_{7}$ in a manner similar to the mechanism mentioned by $\mathrm{He}$ and Suito. ${ }^{4}$ This is confirmed by the XRD analysis in Fig. 6. Therefore, it can be said that the immobilizing ability of fluorine dissolved from the slag (sample 6) increased due to the aforementioned hydrates.

Recently, the dissolution of fluorine from slag has become a major environmental issue, due to the tough environmental regulations. This study implies that high oxygen partial pressure at the molten flux state and at least during solidification will be helpful to reduce the fluorine dissolution.

\section{Conclusion}

From the study, the authors have reached following conclusions:

(1) The slag rapidly solidified from molten flux at low $P_{\mathrm{O}_{2}}\left(<10^{-2} \mathrm{~Pa}\right)$ has appreciable amount of Mayenite, Periclase $\left(\mathrm{Mg}_{1-x} \mathrm{Fe}_{x} \mathrm{O}\right)$, Calcia, and $\alpha$-Fe. However, as the $P_{\mathrm{O}_{2}}$ becomes higher $\left(>10^{-2} \mathrm{~Pa}\right)$, the volume fraction of Brownmillerite increases with the expense of those phases.

(2) In the low $P_{\mathrm{O}_{2}}$ processed slag has large fraction of Mayenite phase, which mainly incorporates fluorine. The empty space in the intercalated layer of tetrahedron between octahedron layers should be the preferable site for the fluorine incorporation, but loosely bound. Such a slag 
liberates large amount of fluorine to an aqueous solution.

(3) In the high $P_{\mathrm{O}_{2}}$ processed slag, fraction of Mayenite is insignificant. Rather, $\mathrm{CaF}_{2}$ particles incorporate fluorine. The particular morphology and phase stability keeps fluorine from dissolution.

\section{REFERENCES}

1) H. Mizukami, M. Ishikawa, T. Hirata, T. Kamiyama and K. Ichikawa: ISIJ Int., 44 (2004), 630.

2) R. Inoue and H. Suito: ISIJ Int., 42 (2002), 785.

3) H. He and H. Suito: ISIJ Int., 41 (2001), 513.

4) H. He and H. Suito: ISIJ Int., 42 (2002), 794.

5) H. Suito and R. Inoue: ISIJ Int., 42 (2002), 921.

6) H. Mizukami, M. Ishikawa, T. Hirata, T. Kamiyama and K.
Ichikawa: ISIJ Int., 44 (2004), 623.

7) H. He and H. Suito: ISIJ Int., 41 (2001), 506.

8) R. Inoue and H. Suito: ISIJ Int., 42 (2002), 930

9) E. T. Turkdogan: Physical Chemistry of High Temperature Technology, Academic Press, New York, (1980), 7.

10) F. D. Richardson and J. H. E. Jeffes: J. Iron Steel Inst., 160 (1948), 261

11) L. S. Darken and R. W. Gurry: Physical Chemistry of Metals, McGraw-Hill, NY, (1953), 349.

12) ASTM E 246-95, Annual Book of ASTM Standards, Vol. 03.05, (2000), 249.

13) Z. Xu, J. Hwang, R. Greenlund and S. Anschuetz: J. Min. Mater. Charact. Eng., 2 (2003), 65.

14) G. J. Redhammer, G. Tippelt, G. Roth and G. Amthauer: Am. Minerall., 89 (2004), 405.

15) F. D. Tamas and A. Vertes: Cem. Concr. Res., 3 (1973), 575. 